\title{
ЕКОНОМІКА
}

$\begin{gathered}\text { Науковий вісник НлтУ України } \\ \text { Scientific Bulletin of UNFU } \\ \text { https://nv.nltu.edu.ua }\end{gathered}$
$\begin{aligned} & \text { https://doi.org/10.36930/40300211 } \\ & \text { Article received 24.03.2020 p. } \\ & \text { Article accepted 04.06.2020 p. }\end{aligned}$
UDC 697.92

N. A. Spodyniuk ${ }^{1}$, V. B. Shepitchak ${ }^{2}$

${ }^{I}$ National University of Life and Environmental Sciences of Ukraine, Kyiv, Ukraine

${ }^{2}$ Lviv Polytechnic National University, Lviv, Ukraine

\section{ANALYSIS OF THE COST OF HEAT ENERGY AND THE WAYS OF IT'S SAVING FOR RESIDENTIAL BUILDINGS}

The rise in gas prices causes them to switch to alternative fuels such as firewood, coal and fuel briquettes. Replacing a gas boiler with a solid fuel does not require much effort and such a solution was economically feasible given the high cost of electricity as well. However, to date, energy pricing has undergone a realignment. So the question remains how to really save energy and money of consumers. The purpose of the article was to analyze the cost of thermal energy during the heating period for individual buildings given the constant change in price and priorities for a particular fuel. Mathematical estimation of heat losses of an individual building was carried out, based on a number of assumptions and generalizations. Thanks to this technique, it is possible to estimate with sufficient accuracy for engineering calculations, consumption of natural gas, solid fuel and electricity to provide energy to the home heating system. As a result of the analysis, a number of features can be outlined. After rising gas prices, individual homeowners have made a sharp switch to solid fuel heating. In 2016, prices for alternative fuels, such as coal and fuel briquettes, were much lower than the price of gas for the population. Therefore, a solid fuel boiler unit was a good solution to the problems of Ukrainians in the fight against energy dependence. In 2020, the situation changed dramatically. The price of solid fuels has risen and it is difficult to find an alternative to gas now, taking into account the ease of operation of the gas boiler, as opposed to solid fuel. The sharp rise in the price of firewood and coal is associated with high demand and a sharp decrease in solid fuel resources. It should also be noted that the problem of ecology in Ukraine will continue to become increasingly important. Therefore, the use of solid fuel sources of heat will have to be consciously refuse in the near future. Application of local infrared heating system will allow to provide local heating of only some residential zones. Also, the installation of a two-zone or three-zone electricity meter and quality regulation of the infrared heating system will save energy.

Keywords: heat of combustion; fuels; gas prices; electricity meter; infrared heating system.

Introduction. Currently, there are many ways to heat a room in the cold period of the year in Ukraine. Individual homeowners have a greater choice of heat sources than those living in apartments. The rise in gas prices causes them to switch to alternative fuels such as firewood, coal and fuel briquettes. This was a particularly pressing issue during the period of sharp price rise in 2014. Replacing a gas boiler with a solid fuel does not require much effort and such a solution was economically feasible given the high cost of electricity as well.

However, to date, energy pricing has undergone realignment. So the question remains how to actually save energy and residents' own funds.

The object and subject of study. The subject of the study is the energy price policy in Ukraine. The object of study is an individual house that has been heated by different sources of heat.

Purpose and tasks of the study. The purpose of the article was to conduct an analysis of the cost of thermal energy in the heating period for individual buildings given the constant change in price and priorities for a particular fuel.

Scientific novelty of the research and practical significance of the obtained results. Mathematical estimation of heat losses of an individual house was conducted, based on a number of assumptions and generalizations. With this technique, it is possible to estimate with sufficient accuracy for engineering calculations, consumption of natural gas, solid fuel and electricity to provide energy to the individual heating system.

Інформація про авторів:

Сподинюк Надія Андріївна, канд. техн. наук, доцент, кафедра теплоенергетики. Email: n_spoduniuk@meta.ua; https://orcid.org/0000-0002-2865-9320

Шепітчак Володимир Богданович, канд. техн. наук, доцент, кафедра цивільної безпеки. Email: shepitchak@gmail.com; https://orcid.org/0000-0001-5883-548X

Цитування за ДСтУ: Сподинюк Н. А., Шепітчак В. Б. Analysis of the cost of heat energy and the ways of it's saving for residential buildings. Науковий вісник НЛТУ України. 2020, т. 30, № 2. С. 62-65.

Citation APA: Spodyniuk, N. A., \& Shepitchak, V. B. (2020). Analysis of the cost of heat energy and the ways of it's saving for residential buildings. Scientific Bulletin of UNFU, 30(2), 62-65. https://doi.org/10.36930/40300211 
Analysis of Literary Sources. According to the research [4] exhaustion of the world's natural gas reserves and increasing its production on the one and higher consumption on the other, lead to higher natural gas prices each year. This, in turn, increases the share of expenditures in the balance of both the state and the individual building for energy and is increasingly asking questions about the effectiveness of its use.

After the sharp rise in gas prices, solid fuel became the alternative to natural gas. However, with increasing demand, the price of solid fuel has also increased.

In terms of electricity consumption, it is uneven by hours of the day and by season. In residential buildings, about $60 \%$ of electricity is consumed between 18 and 22 hours. In summer, electricity is consumed $15-25 \%$ less than in winter.

Daily load schedule has a pronounced uneven nature with a significant increase in load in the evening and morning and recession at night [1]. Speaking about the use of electric heating private houses, the quality of its regulation and the use of a two-tariff meter will allow to obtain significant energy savings.

Materials and Methods. Consider, for example, a house in Lviv with a total area of $200 \mathrm{~m}^{2}$ with an estimated heat loss of $20 \mathrm{~kW}$. The calculation of the main indicators of building is tabulated (The cost of energy was calculated from the received fuel and electricity costs taking into account electricity tariffs and different types of fuel in 2016 and 2020 (table 1).

The heat consumption for the heating period is calculated by the formula:

$$
Q_{\text {year }}=Q_{h l o s s}\left(\frac{t_{\text {in }}-t_{a v}^{h}}{t_{\text {in }}-t_{\text {out }}^{5}}\right) \cdot n_{h} \cdot 24, \mathrm{~kW} \cdot \mathrm{h}
$$

and is $43180 \mathrm{~kW} \cdot \mathrm{h}$ or $155448 \mathrm{MJ}$ for the heating period.

Here: $Q_{\text {hloss }}-$ heat loss in the house, W; $t_{i n}$-indoor air temperature, ${ }^{\circ} \mathrm{C} ; t_{a v}^{h}$ - ambient temperature of the heating period, ${ }^{\circ} \mathrm{C} ; t_{\text {out }}^{5}-$ ambient temperature is the coldest five days, ${ }^{\circ} \mathrm{C} ; n_{h}$-duration of heating period, days.

Fuel consumption was calculated with heating of this building with different types of fuel. Natural gas, coal from the Volyn deposit, firewood and fuel briquettes or pellets were considered.

The consumption of gas and solid fuels was determined by the formula [5]:

$$
B_{\mathrm{p}}=\frac{Q_{\text {year }}}{Q_{H}^{p} \cdot \eta}, \mathrm{m}^{3} .
$$

Where $Q_{k}^{p}$ - lower estimated heat of combustion of the specified fuel, $\mathrm{MJ} / \mathrm{m}^{3} ; \eta$ - efficiency of the selected type of boiler unit.

For comparison, the calculation of electricity consumption when was the heating of the house with an electric boiler was calculated.

Electricity consumption was determined by the formula:

$$
N=\frac{Q_{\text {year }}}{k}, \mathrm{~kW} \cdot \mathrm{h} \text {. }
$$

Where $k$ - coefficient of transformation of electric energy into thermal energy, $k=0.98$.

The calculation of fuel and electricity consumption is summarized in the table 2 . The cost of energy was calculated from the received fuel and electricity costs taking into account electricity tariffs and different types of fuel in 2016 and 2020 (table 3).

Table 1. Basic indicators of the object

\begin{tabular}{|c|c|c|c|c|c|c|}
\hline $\begin{array}{c}\text { The location } \\
\text { of the object }\end{array}$ & $\begin{array}{c}\text { Heating } \\
\text { area, } \mathrm{m}^{2}\end{array}$ & $\begin{array}{c}\text { Heat losses, } \\
\mathrm{kW}\end{array}$ & $\begin{array}{c}\text { Indoor air tem- } \\
\text { perature, }{ }^{\circ} \mathrm{C}\end{array}$ & $\begin{array}{c}\text { Ambient temperature is } \\
\text { the coldest five days, }{ }^{\circ} \mathrm{C}\end{array}$ & $\begin{array}{c}\text { Ambient temperature of } \\
\text { the heating period, }{ }^{\circ} \mathrm{C}\end{array}$ & $\begin{array}{c}\text { Duration of heating } \\
\text { period, days }\end{array}$ \\
\hline Lviv & 200 & 20 & 20 & -19 & 0.4 & 179 \\
\hline
\end{tabular}

Table 2. Calculation of fuel and electricity consumption

\begin{tabular}{|c|c|c|c|}
\hline Type of fuel & $\begin{array}{c}\text { Lower estimated heat of combustion of } \\
\text { the specified fuel, } \mathrm{MJ} / \mathrm{m}^{3}\end{array}$ & $\begin{array}{c}\text { Efficiency of the selected type } \\
\text { of boiler unit }\end{array}$ & Fuel consumption \\
\hline Natural gas & 35.6 & 0.93 & $4695\left(\mathrm{~m}^{3}\right)$ \\
\hline Coal & 21.44 & 0.8 & $9.06(\mathrm{t})$ \\
\hline Firewood & 10.21 & 0.8 & $19.031(\mathrm{t})$ \\
\hline Fuel briquettes, granules & 17.5 & 0.8 & $11.103(\mathrm{t})$ \\
\hline Electricity & - & 0.98 & $44061(\mathrm{~kW} \cdot \mathrm{h})$ \\
\hline
\end{tabular}

Table 3. Energy cost in 2016

\begin{tabular}{|c|c|c|c|}
\hline Type of fuel & Fuel consumption & Price per unit & Energy cost, UAH \\
\hline Natural gas & $4695\left(\mathrm{~m}^{3}\right)$ & $6.879 \mathrm{UAH} / \mathrm{m}^{3}$ & 32297 \\
\hline Coal & $9.06(\mathrm{t})$ & $3100 \mathrm{UAH} / \mathrm{t}$ & 28086 \\
\hline Firewood & $19.031(\mathrm{t})$ & $1000 \mathrm{UAH} / \mathrm{t}$ & 19031 \\
\hline Fuel briquettes, granules & $11.103(\mathrm{t})$ & $2000 \mathrm{UAH} / \mathrm{t}$ & 22206 \\
\hline Electricity & $44061(\mathrm{~kW} \cdot \mathrm{h})$ & & 65171 \\
\hline
\end{tabular}

Table 4. Energy cost in 2020

\begin{tabular}{|c|c|c|c|}
\hline Type of fuel & Fuel consumption & Price per unit & Energy cost, UAH \\
\hline Natural gas & $4695\left(\mathrm{~m}^{3}\right)$ & $5.40 \mathrm{UAH} / \mathrm{m}^{3}$ & 25353 \\
\hline Coal & $9.06(\mathrm{t})$ & $4500 \mathrm{UAH} / \mathrm{t}$ & 40770 \\
\hline Firewood & $19.031(\mathrm{t})$ & $2300 \mathrm{UAH} / \mathrm{t}$ & 43771 \\
\hline Fuel briquettes, granules & $11.103(\mathrm{t})$ & $3200 \mathrm{UAH} / \mathrm{t}$ & 35530 \\
\hline Electricity & $44061(\mathrm{~kW} \cdot \mathrm{h})$ & & 73945 \\
\hline
\end{tabular}


Research results. Analysis of fuel prices in 2016 showed that when natural gas prices rose for the population, prices for solid fuel were low. Prices for all fuels are rising in 2020 however the cost of natural gas for the population is estimated as the sum of the cost of gas for its use plus the cost of gas for its transportation. To compare prices, see Figure 1.

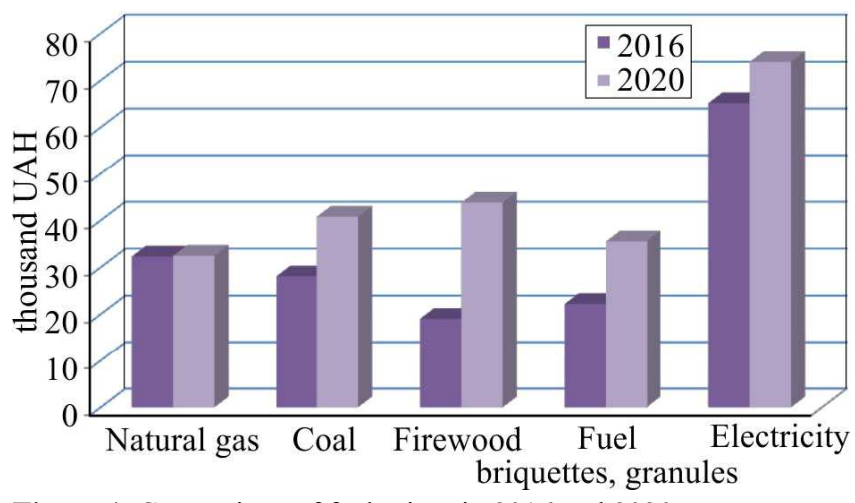

Figure 1. Comparison of fuel prices in 2016 and 2020

As the tables and charts show, the cost of fuels has increased in 2020, except gas. Compared to other fuels, the cost of natural gas has decreased by $21.5 \%$. This is a result of a reduction in gas tariff, not a reduction in total gas consumption. In the future it is necessary to pay attention to reorientation of heat sources for more fuel efficient [2].

Discussion of the obtained results. As a result of the analysis, a number of features can be outlined. After changing gas prices, individual homeowners have made a sharp transition to solid fuel heating. And as you know, demand generates supply. In 2016, prices for alternative fuels, such as coal and fuel briquettes, were much lower than the price of gas for the population. Therefore, a solid fuel boiler unit was a good solution to the problems of Ukrainians in the fight against energy addiction. In 2020, the situation changed dramatically. The price of solid fuels has increased and gas alternatives are hard to come by now, taking it into consideration that the gas boiler unit is easy to operate, unlike solid fuel one.

The sharp rise in the price of firewood and coal is associated with high demand and a sharp decline in solid fuel resources. It's also worth noting that the problem of ecology in Ukraine will continue to become increasingly important. Therefore, the use of solid fuel sources of heat will have to be deliberately abandoned in the near future.

The most expensive source of heat is electricity. However, looking at the statistics of past years, can conclude that compared to the cost of traditional fuels, electricity may be a good alternative to other fuels in the near future, with its proper economic use.

In the same individual building for $200 \mathrm{~m}^{2}$, it is advisable to develop a zonal heating system with alternative heaters such as electric infrared heaters [3]. The use of such a system will allow providing local heating only in certain residential areas where people are located. This will eliminate the need to heat the entire volume of the room, unlike traditional heating systems with solid fuel or gas boiler unit (Fig. 2) [6].

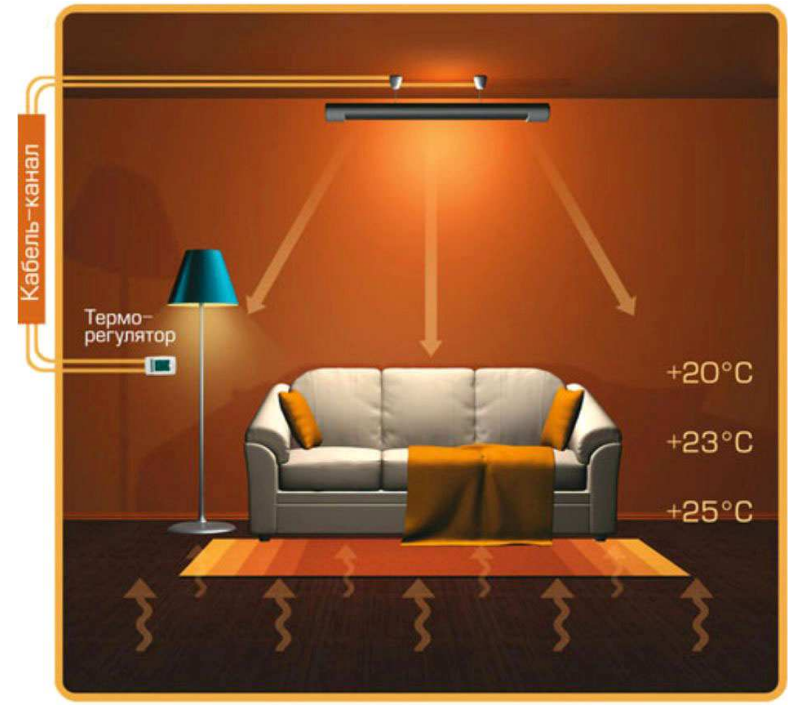

Figure 2. The use of infrared heaters in residential buildings

Conclutions. Electricity remains an alternative to natural gas among the traditional fuels in Ukraine. The rise in price of fuel and heat is an economical prerequisite for electrification of public utilities. This allows in some cases to talk about the cost-effectiveness of electrification of heating systems.

The price of fuel briquettes has increased by $37.4 \%$, of coal has increased by $31.1 \%$. The price of firewood increased the most, by almost $56.5 \%$. This explains the rapid response of the population to finding an alternative to natural gas.

Using local electric infrared heating will allow local heating only individual residential areas. Using an electric infrared heater will increase the efficiency of the heating system by $60 \%$.

Also installing a two-zone or three-zone electricity meter and good regulation of the infrared heating system will save energy.

\section{References}

1. Malyarenko, V. A., Shcherbak, I. E., Kolotilo, I. D., \& Lysak, L. V. (2014). Vozmozhnosti integratsii elektroenergii v sistemah goryachego vodosnabzheniya $\mathrm{ZhKH}$. Energy saving. Energy. Energy audit, 3(121), 53-57.

2. Shapoval, S., Shapoval, P., Zhelykh, V., Pona, O., Spodyniuk, N., Gulai, B., Savchenko, O., \& Myroniuk, Kh. (2017). Ecological and energy aspects of using the combined solar collectors for lowenergy houses. Chemistry \& chemical technology, 11(4), 503508. https://doi.org/10.23939/chcht11.04.503

3. Shepitchak, V., Zhelykh, V., \& Spodyniuk, N. (2016). Study of peculiarities of surface irradiation with parallel arrangement of infrared heater. Budownictwo o zoptymalizowanym potencjale energetycznym, 1(17), 81-84. https://doi.org/10.17512/bozpe.2016.1.12

4. World Energy. (2019). BP Statistical Review of World Energy, 68, 62. Retrieved from: https://www.bp.com/en/global/corporate/energy-economics/statistical-review-of-world-energy.html.

5. Yurkevich, Yu., \& Spodyniuk, N. (2016). Device for pneumatic overload of fuel pellets. Budownictwo o zoptymalizowanym potencjale energetycznym, 1(17), 99-104. https://doi.org/10.17512/bozpe.2016.1.15

6. Zhelykh, V., Spodyniuk, N., Gulai, B., \& Shepitchak, V. (2017). Modeling of the process of heat regime formation in the irradiation area of infrared heater. Construction of optimized energy potential, 2(20), 83-90. https://doi.org/10.17512/bozpe.2017.2.11 
${ }^{1}$ Національний університет біоресурсів і природокористування Украӥни, м. Київ, Украӥна ${ }^{2}$ Національний університет "Львівська політехніка", м. Львів, Україна

\section{АНАЛІЗ ВАРТОСТІ ТЕПЛОВОЇ ЕНЕРГІЇ ТА ШЛЯХИ ЇЇ ЕКОНОМІї дЛя ЖИТЛОВИХ БУдинкІВ}

Здорожчання ціни на газ провокує переходити на альтернативні види палива, такі як дрова, вугілля та паливні брикети. Заміна газового котла на твердопаливний не потребує багато зусиль, і таке рішення проблеми було економічно доцільним, 3 огляду на високу вартість електроенергії також. Проте на сьогодні цінова політика на енергоресурси зазнала перебудови. Тож відкритим залишається питання, як насправді варто економити енергію та власні кошти. Тому у цьому дослідженні проаналізовано вартість теплової енергії в опалювальний період для індивідуальних житлових будинків з урахуванням постійної зміни ціни та пріоритетів на той чи інший вид палива. Виконано математичну оцінку тепловтрат індивідуального будинку на підставі низки припущень та узагальнень. Завдяки цій методиці можливо оцінити, з достатньою для інженерних розрахунків точністю, витрату природного газу, твердого палива та електроенергії на забезпечення енергією системи опалення житлового будинку. За результатами виконаного аналізу можна окреслити низку особливостей. Після зростання ціни на газ, власники індивідуальних будинків здійснили різкий перехід на опалення твердим паливом. У 2016 р. ціни на альтернативні види палива, такі як кам'яне вугілля та паливні брикети, були набагато нижчими за ціну на газ для населення. Тому твердопаливний котел був добрим рішенням проблем українців у боротьбі з енергетичною залежністю. У 2020 р. ситуація стрімко змінилася. Ціна на тверде паливо зросла і натепер альтернативу газу важко знайти, якщо ще і взяти до уваги простоту в експлуатації газового котла, на відміну від твердопаливного. Стрімке підняття ціни на дрова та вугілля пов'язане 3 великим попитом та різким зменшенням твердопаливних ресурсів. Також варто зазначити, що проблема екології в Україні надалі буде набувати дедалі більшого значення. Тому від використання твердопаливних джерел теплопостачання потрібно буде свідомо відмовлятися в недалекому майбутньому. Застосування локальної системи інфрачервоного опалення дасть змогу забезпечити локальний нагрів тільки окремих житлових зон. Також встановлення дво- або тризонного лічильників електроенергії та якісне регулювання системи інфрачервоного опалення дасть змогу заощадити енергоносії.

Ключові слова: теплота згоряння палива; ціни на газ; лічильник електроенергії; інфрачервона система опалення. 